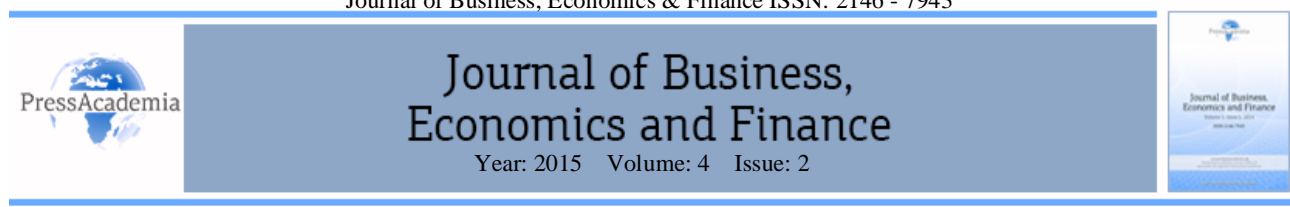

\title{
FACTORS INFLUENCING THE CREDIT RATIONING ON THE COMMERCIAL LENDING PROCESS
}

\section{DOI: 10.17261/Pressacademia.2015211618}

\author{
H. Ali ATA ${ }^{1}$, Mehmet KORPI ${ }^{2}$, Mustafa UGURLU ${ }^{3}$, Fethullah SAHIN ${ }^{4}$ \\ 'University of Gaziantep. E-mail: ata@gantep.edu.tr \\ 2University of Gaziantep. E-mail: korpi@gantep.edu.tr \\ ${ }^{3}$ University of Gaziantep. E-mail: ugurlu@gantep.edu.tr \\ ${ }^{4}$ Melikşah University. E-mail: fsahin@meliksah.edu.tr
}

\section{Keywords: \\ Asymmetric Information, Credit Rationing, Commercial Lending, Logistic Regression, Discriminant Analysis.}

Jel Classification: G21, E44, C19

\begin{abstract}
Adverse selection and moral hazard problem that arise due to asymmetry of information is often observed in banking sector. Accordingly, banks use credit rationing mechanism in order to mitigate the losses that arise due to asymmetric information. In this study the concept of credit rationing mechanism applied by banks is examined by exploring the manufacturing firms from various sectors which applied for a corporate loan in 2103. Logistic regression and discriminant analysis were employed in order to estimate the credit rationing. The results indicate that morality, credit history, and liquidity variables have significant impact in the commercial lending process.
\end{abstract}

\section{INTRODUCTION}

An important feature of financial markets is the asymmetry of information that is defined as a situation in which one party -generally a borrower- in a transaction has more or superior information than another (mostly lender) party. The concept of asymmetric information was first introduced through Lemon Theory which was developed by George Akerlof (1970), who was later awarded with the Nobel Prize. Afterwards, this theory was studied in various contexts including labor, insurance, loan and capital markets. Asymmetric information in credit markets arises due to the failure of lenders and borrowers to exchange complete and correct information between each other. In a financial transaction, borrowers will have more information than lenders about their past default and likelihood of subsequent default, ability to repay, and the use of loan. This situation will lead to credit rationing where lenders either will not issue the loan or reduce the amount of loan. According to Frederic Mishkin, asymmetric information in financial markets leads to two primary problems that are Adverse Selection and Moral Hazard.

In financial markets, adverse selection is an ex-ante problem that occurs between lenders and borrowers where banks or financial institutions issue a loan to a risky customer. Adverse selection occurs when a borrower with a high credit risk and low credibility is willing to borrow loan and pay the high interest rate. 
For example, a bank sets one price (interest rate) for all of its loans and the adversely selected customers are those who are risky ones and have a low potential for repayment of the loan. Adverse selection problem in credit markets can be mitigated through collateral requirements and credit rating services. Moral Hazard is an ex-post problem that arises between lenders and borrowers after a transaction occurs. It arises because an individual or institution does not consider the full consequences and responsibilities of its actions and hence has a tendency to act less carefully. In credit markets, moral hazard problem refer to a situation where borrowers do not use the fund for the specified purpose. Moral hazard problem occurs as a result of the inability on part of the lenders in monitoring the operations of borrowers and can be mitigated by close monitoring of the borrowers after a loan is issued (Atiyas et al, 1993:2). While adverse selection problem occurs before the transaction, moral hazard problem is seen after entering into a contract.

Credit rationing is limiting the supply of additional credit (loan) to the borrowers who are even willing to repay with higher interest (Jaffe and Russell, 1976:651). Credit rationing happens when demand for loans exceeds the supply. If lenders limit credits, due to adverse selection and moral hazard, for borrowers who have agreed to repay them, credit (loan) is rationed $(\mathrm{Er}, 2011: 311)$ In the literature, there are two types of theories in credit rationing. The first type of theory about credit rationing was developed by Jaffee and Russell (1976). According to their theory, the credit rationing occurs if lenders issue the credit less than what was demanded by borrowers. The second type of credit rationing theory was developed by Stiglitz and Weiss in 1981. In this theory, they argued that lenders implement credit rationing by declining (denying) the credit application entirely. The rest of this paper is organized as follows; the second part of this paper provides an empirical literature review on credit rationing, in the third part the dataset and methodology are presented, in the fourth part, the empirical result and findings are explained, and the last part concludes the study.

\section{LITERATURE REVIEW}

The modern literature on credit rationing dates back to John $\mathrm{M}$. Keynes's studies on Money. Hodgam (1960, 1962) was the first who actually studied the modern credit rationing in his researches. He explained the causes of credit rationing through economic reasons rather than institutional factors. The following researches are conducted in credit rationing from different perspectives. According to Petersen and Rajan, 1994, banking relationships seem to lessen credit rationing because banks can easily monitor and access information regarding borrowers' history and actions. Similarly, Berger and Udell (1995) found that the length of relationship lowers both the loan rate premiums and the likelihood of collateral requirements. Cole (1998) concludes that a previous experience with a lender increases the likelihood of credit availability and thus decreases the credit rationing.

Another important factor that mitigates the credit rationing is the age of the firms. Diamond, 1991, and Oliner and Rudebusch, 1992, have found that in credit rationing firm age is an indicator of firm's quality, since longevity may contain a signal for survival ability and quality of management, as well as the accumulation of reputational capital. 
Moreover, the information gap is relatively smaller for older firms given their longer track record (Petersen and Rajan, 1994; Cressy, 1996). In addition; recent studies have indicated that the likelihood of credit rationing increases for more innovative firms. In particular, when the loan applicant requires funding for specific, intangible and highly innovative investment, such as those in R\&D, rationing may be more likely (Freel, 2007 and Piga and Atzeni, 2007). External auditing and international accounting standards are also thought to reduce firm denseness by increasing the transparency of financial accounts. Dharan (1993) points out that the auditor's opinion is assumed to convey, without error, the risk characteristics of the firm to the lenders. Given that external auditing is costly, firms that choose to do so actually send a quality signal to potential lenders (Konstantinos and Nicholas 2011). According to Cole, 1998; Rajan and Zingales, 1998; Beck and Levine, 2002; Cowling and Mitchell, 2003, industrial heterogeneity has considerable impact on the credit rationing mechanism. Another factor that affects the credit rationing is the managerial ability (Cavalluzzo et al., 2002). In his study, Hubbard (1998) states that a firm's investment opportunity set may also affect the likelihood of rationing.

\section{DATA AND METHODOLOGY}

In this study, we obtained data from a state bank (bank-level data) that operates in Gaziantep region in Turkey. The data set includes quantitative and qualitative factors for 100 firms operating in manufacturing sector which applied for a corporate loan in 2013. We were only able to include 77 firms to the analysis due to the missing data of firms. All firms are classified into two groups; non-rationed and credit rationed firms based on loan approval. Accordingly, if a loan application is approved and granted in full then the firm is considered non credit rationed firm. However, if the loan application was rejected or partially granted then the firm is regarded as credit rationed. Thus, the depended variable here takes binomial value 1 for rationed firm and 0 for non-rationed firm. The factors that might influence the credit rationing are indicated as follow, firm size $(x 1)$, firm age and ownership structure $(x 2)$, bank relations $(x 3)$, foreign trade status $(x 4)$, the administrative structure $(x 5)$, morality $(x 6)$, liquidity $(x 7(A))$, the asset structure $(x 7(B))$, the capital structure and leverage $(x 7(C))$, profitability, and productivity $(x 7(D))$, the performance ratios ( $x 7(e))$ and the credit history ( $x 8)$. Each factor is scored between 1 and 4 by the bank where 1 indicates lower risk measure and the score of 4 specifies higher risk measure. The variables, abbreviations and codes used in the study are shown in appendix 1.

Firm size is one of the independent variables which defined as total annual net sales of the firms in the sample. As total net sales increases, the credit risk hence probability of credit rationing is expected to decreases. The next independent variable is firm age which indicates the history of the company which is indicator of firm's reputation and livability. Bank relationship variable defined as firm's past experienced with banks and the variable is expected to have negative relationship with credit rationing. Foreign trade (export and import) status; the variable specify whether or not the firm has any international business relationship. Foreign trade variable is expected to have negative impact on the credit rationing. If a firm does not involve any foreign trade, either by exporting or importing, the variable was not used in the analysis. 
Administrative structure; the variable indicates the type of management and total experience of the professionals in the firm. Morality is classified as firm's past borrowing experience (how a firm fulfilled its obligations) and higher morality indicates lower credit rationing. Liquidity variable explains the power of firms to meet the short-term liabilities. The higher the liquidity of a firm the lower credit rationing will be. Asset structure variable explains how firm's assets are allocated and effectively utilized? Capital structure and indebtedness; defined as the total debt level and leverage ratio. Profitability and efficiency variable indicate the relationship between firm's sales, profitability and credit rationing. Performance ratios: the ratio measures impact of performance ratio on the credit rationing. Credit history is the last variable in the analysis provides information about a firm's past loan growth and credit information.

\section{EMPIRICAL RESULTS}

In this study, we first performed a correlation analysis in order to test whether or not there is a significant correlation among the variables. Correlation analysis proves the multicollinearity problem by measuring the linearity of the relationship between variables. Multicollinearity occurs when two or more variables in a model are correlated and provide abundant information about the response. As indicated in appendix 2, no significant correlation was found among the variables. Tolerance and Variance Inflation Factor (VIF) were also examined to test whether or not there is a significant Multicollinearity problem between the variables. Menard (1995) indicates that if the tolerance value is $<0.1$, then there is a serious multicollinearity problem in the model, and if it is $<0.2$, then there is a potential multicollinearity problem. According to Myers (1990), the multicollinearity problem appears in a model if the VIF value is greater than 10. Field (2005) states that the average VIF score that is close to 1 indicate that multicollinearity problem does not exist in a model. According to Cokluk (2010), the standard error of regression coefficients $(\beta)$ should be evaluated in order to figure out the multicollinearity problem. If the standard error of all variables is less than 2 , it is considered that multicollinearity problem does not exist. 
Table 1: The test of Multicollinearity Problem with Standard Error,

Tolerance and VIF Values.

Coefficients(a)

\begin{tabular}{|ll|r|r|r|r|}
\hline \multirow{2}{*}{ Model } & \multicolumn{2}{|c|}{$\begin{array}{c}\text { Unstandardized } \\
\text { Coefficients }\end{array}$} & \multicolumn{2}{c|}{ Collinearity Statistics } \\
\cline { 3 - 6 } & \multicolumn{1}{c|}{ B } & Std. Error & Tolerance & \multicolumn{1}{c|}{ VIF } \\
\hline 1 & (Constant) & $-4,218$ & 1,561 & & \\
& Size & 0,047 & 0,119 & 0,668 & 1,496 \\
& Age & $-0,010$ & 0,125 & 0,734 & 1,363 \\
& Relation & $-0,100$ & 0,207 & 0,471 & 2,121 \\
& Export & 0,194 & 0,140 & 0,729 & 1,372 \\
& Admin & 0,408 & 0,404 & 0,494 & 2,024 \\
& Character & 1,201 & 0,737 & 0,784 & 1,276 \\
& Liquidity & 0,133 & 0,090 & 0,547 & 1,827 \\
& Asset & $-0,129$ & 0,130 & 0,710 & 1,408 \\
Leverage & 0,228 & 0,130 & 0,454 & 2,204 \\
& Profit & 0,016 & 0,061 & 0,768 & 1,302 \\
Performance & 0,063 & 0,092 & 0,823 & 1,215 \\
History & 0,128 & 0,068 & 0,830 & 1,205 \\
\hline
\end{tabular}

As seen in Table 1, the standard error of the independent variables was found to be less than 2; the tolerance value for all variables was found to be more than 0.2 and the VIF value for all variables appears to be less than 10 . Therefore, the problem of multicollinearity between the independent variables does not exist. Durbin-Watson (DW) statistics test is used to identify the presence of autocorrelation problem in the regression analysis. The value of DW statistics lies between 0 and 4 . The value close to 0 indicates positive serial correlation, the value close to 4 indicates negative autocorrelation problem and the DW value around 2 indicates no autocorrelation. As seen in Table 2, the DW value was found 2,373 and the result concludes that there is no autocorrelation problem in the model.

Table 2: Autocorrelation Problem

Model Summary(b)

\begin{tabular}{|c|c|}
\hline Model & Durbin-Watson \\
\hline 1 & 2,373 \\
\hline
\end{tabular}

a. Predictors: (Constant), History, Export, Character, Leverage, Performance, Asset, Profit, Age, Size, Admin, Liquidity, Relation 
b. Dependent Variable: Rationing

\subsection{Discriminant Analysis and Results}

Discriminant analysis is one of multivariate statistical techniques which aim to predict the relationship between the categorical variables and metric independent variables (Kalaycl, 2008: 335). Discriminant analysis has two main objectives: separation and classification. If the first objective (seperation) was used in an analysis the model is called Descriptive Discriminant Analysis for the second objective the model is specified as Predictive Discriminant Analysis (Özdamar, 1999:320).

SPSS 18.0 statistical analysis program was used to analyze the data. 12 different variables included in the analysis and only 3 variables found as significant determinants of credit rationing. In disciriminant method there are three assumptions to minimize the misclassification and provide optimal analysis: equal covariance, the lack of multiple connections and normal distribution. In order to apply the discriminant analysis for the data, group must have equal covariance matrix. Equal variance assumption is tested by Box's M statistic. The significant Box's M statistics show the deviation from normality or unequal covariance matrix or both (Albayrak, 2006: 63). Although homogeneity of variance and covariance matrix is the main assumptions, discriminant analysis still can be performed where the covariance matrix is not equal. When the data tested by Box-M Statistic, the results indicate that Box's $M=35,117, F=5,595, p<0,01$, the covariance matrix is not homogenous.

Table 3: Eigenvalue

\begin{tabular}{|c|c|c|c|c|}
\hline Function & Eigenvalue & Variance & Cumulative & $\begin{array}{c}\text { Canonical } \\
\text { Correlation }\end{array}$ \\
\hline 1 & $0,388 \mathrm{a}$ & 100,0 & 100,0 &, 529 \\
\hline
\end{tabular}

As shown in Table 3, since initially two groups were determined one discriminant function was derived. The higher Eigenvalue indicate that the larger part of the variance in the dependent variable is explained by the function. Canonical discriminant function explains $100 \%$ of the total variance. The resulting function is statistically significant. Eigen value of this function is 0.388 .

Table 4: Wilk's Lambda Value

\begin{tabular}{|c|r|r|r|r|}
\hline Function Test & Wilks' Lambda & \multicolumn{1}{c}{ Ki-Square } & \multicolumn{1}{c|}{ Sd } & Anl. \\
\hline 1 &, 721 & 24,082 & 3 &, 000 \\
\hline
\end{tabular}

Table 4 indicates the ratio that was not explained by the total variance of discriminant scores of Wilk's Lambda statistics. In the test conducted by Wilks' Lambda, the first function Wilks' Lambda value of 0.721 (i.e. $72.1 \%$ of the total variance) cannot be explained by the groups. 
Table 5: Canonical Discriminant Coefficients

\begin{tabular}{|l|r|}
\hline \multirow{2}{*}{} & \multicolumn{1}{|c|}{ Function } \\
\cline { 2 - 2 } & \multicolumn{1}{|c|}{1} \\
\hline Character & 6,093 \\
\hline Liquidity & 1,124 \\
\hline History &, 567 \\
\hline Constant & $-16,089$ \\
\hline
\end{tabular}

As seen Table 5, among 12 factors 3 variables namely Character, Liquidity and History were found statistically significant and included in the model. The discriminant equation result is given below. The morality variable is the most effective variable for the Z-score value in the discriminant equation.

$$
Z_{\text {score }}=-16,089+6,093 \text { Character }+1,124 \text { Liquidity }+0,567 \text { History }
$$

Table 6: Average Group Discrimination Function Values

\begin{tabular}{|l|c|}
\hline \multirow{2}{*}{} & Function \\
\cline { 2 - 2 } & 1 \\
\hline No Credit Rationing & $-0,561$ \\
\hline Credit Rationing & 0,673 \\
\hline
\end{tabular}

In Table 6, the average separation function scores for each company (group) are presented. In other words it is found that $Z=\frac{N_{a} Z_{b}+N_{b} Z_{a}}{N_{a}+N_{b}}=0,112$. Accordingly the following classification was carried out; if $Z$ score value is greater than $>Z$, then there was found credit rationing or vice versa.

Table 7: Discriminant Analysis Classification Success

\begin{tabular}{|c|c|c|c|c|c|}
\hline \multicolumn{2}{|c|}{$\begin{array}{c}\text { Discriminant } \\
\text { Analysis }\end{array}$} & \multicolumn{4}{c|}{ Estimated Group } \\
\cline { 2 - 6 } \multicolumn{2}{|c|}{} & 0 & 1 & Total & $\begin{array}{c}\text { Accuracy } \\
\text { Percentage }\end{array}$ \\
\hline \multirow{2}{*}{$\begin{array}{c}\text { Observed } \\
\text { Group }\end{array}$} & 0 & 30 & 12 & 42 & 71,4 \\
\cline { 2 - 6 } & 1 & 8 & 27 & 35 & 77,1 \\
\cline { 2 - 6 } & Total & 38 & 39 & 77 & 74,0 \\
\hline
\end{tabular}

In table 7, the classification value of the 77 companies obtained from discriminant analysis is presented. The model estimated the credit rationing with $71.4 \%$ (30 out of 42 ) and 77.1 $\%$ (27 out of 35) accuracy for the non-credit rationed and credit rationed firms respectively. The total correct classification success for 77 companies is recorded as $74 \%$. 


\subsection{Logistic Regression Analysis and Results}

We also employed in order to identify the factors that affect the credit rationing in a loan approval process. Logistic regression or logit regression as a statistical modeling technique is used to predict the outcome of a categorical dependent variable, such as class or label, based on one or more independent variables. The purpose of this method is to build the most appropriate model which identifies the relationship between independent and dependent variable with minimum input (variable) (Çokluk, 2010:1359). In general, multivariate logistic regression model is defined as follows (Ozdamar, 2004:590);

$$
\mathrm{P}(\mathrm{Y})=\frac{\mathrm{e}^{\mathrm{Z}}}{1+\mathrm{e}^{\mathrm{Z}}}
$$

where $Z$ is a linear combination of independent variables.

$$
Z=\beta_{0}+\beta_{1} X_{1}+\beta_{2} X_{2}+\cdots+\beta_{p} X_{p}
$$

where $\beta_{0}, \beta_{1}, \beta_{2}$ and $\beta_{n}$ are regression coefficients.

In logistic regression method, binary logistic regression analysis is used if the dependent variable consists of categorical variable with two options (Cokluk, 2010:1362-1363). Since the dependent variable is a categorical variable with two different outputs, we used Binary Logistic Regression Analysis in this study.

The hypotheses of the model can be constructed as follows;

$$
\begin{aligned}
& \mathrm{H}_{0}: \beta_{0}=\beta_{1}=\beta_{2}=\cdots=\beta_{p} \\
& \mathrm{H}_{1}: \beta_{0} \neq \beta_{1} \neq \beta_{2} \neq \cdots \neq \beta_{p}
\end{aligned}
$$

\begin{tabular}{|c|c|c|c|}
\hline & $\begin{array}{c}\text { Chi- } \\
\text { square }\end{array}$ & $d f$ & Sig. \\
\hline Step & 3,963 & 1 & 0,047 \\
\hline Block & 29,729 & 4 & 0,000 \\
\hline Model & 29,729 & 4 & 0,000 \\
\hline
\end{tabular}

Table 8: Omnibus Tests of Model Coefficients

In Table 8, the omnibus test which measures whether or not they explained variance in a set of data is significantly greater than the overall unexplained variance is presented. The model is found to be significant at the 0.95 confidence level. 
Table 9: Model Summary

\begin{tabular}{|c|c|c|c|}
\hline & $\begin{array}{c}-2 \text { Log } \\
\text { likelihood }\end{array}$ & $\begin{array}{c}\text { Cox \& Snell } \\
\text { R Square }\end{array}$ & $\begin{array}{c}\text { Nagelkerke } \\
\text { R Square }\end{array}$ \\
\cline { 2 - 4 } & 76,379 & 0,320 & 0,428 \\
\hline
\end{tabular}

In Table 9, Cox \& Snell R Square and Nagelkerke R Square scores indicate the amount of variance explained by the logistic model. Higher Nagelkerke R Square score indicates better model fit and the $\mathrm{R}$ square score that is equal to 1 shows perfect model fit (Cokluk, 2010:1386). Nagelkerke R Square was found to be 0.428 and the score indicates that 42.8 percent of the model is explained by the independent variables. The -2 log likelihood value is used for investigating the contribution of independent variables to the model and testing the significance of the regression coefficients (Avci, 2011:97). The -2 log likelihood is found to be 76.379 at $95 \%$ confidence level. In the initial model that includes only the constant term, the -2 log likelihood value is found to be 106,107 , but at the end of the fourth step, the value is found to be 76,379 . The decreasing -2 log likelihood indicates improvement in model-data fit as independent variables are added to the model.

The Hosmer-Lemeshow test is used to measure the goodness of fit for logistic regression models. This test examines whether or not all logistic regression (logit) coefficients (except the constant) term is equal to zero.

$\mathrm{H}_{0}$ : There is no significant difference between observed and predicted value in the model.

$\mathrm{H}_{1}$ : There is significant difference between observed and predicted value in the model.

Table 10: Hosmer and Lemeshow Test

\begin{tabular}{|c|c|c|c|}
\hline & Chi-square & $\mathrm{df}$ & Sig. \\
\cline { 2 - 4 } & 14,771 & 8 & 0,064 \\
\hline
\end{tabular}

As seen in Table 10, since the chi-square value of the model with 8 degrees of freedom $(14,771)$ is found to be less than $\chi^{\wedge} 2(0.05,8)=15.51, \mathrm{H}_{0}$ hypothesis is not rejected. 
Table 11: Classification Table

\begin{tabular}{|c|c|c|c|}
\hline \multirow{3}{*}{ Observed } & \multicolumn{3}{|c|}{ Predicted } \\
\hline & \multicolumn{2}{|c|}{ Rationing } & \multirow{2}{*}{$\begin{array}{c}\text { Percentage } \\
\text { Correct }\end{array}$} \\
\hline & 0 & 1 & \\
\hline Rationing & 34 & 8 & 81,0 \\
\hline & 9 & 26 & 74,3 \\
\hline Overall Per & & & 77,9 \\
\hline
\end{tabular}

In Table 11, the classification scores obtained from logistic regression model are presented. The ratio of the total correct classification of the model at $5 \%$ significance level is found to be $77.9 \%$. The model correctly estimates 34 of 42 non-rationed companies and 26 of 35 credit rationed firms.

Table 12: Estimated Coefficients Variables in the Equation

\begin{tabular}{|r|r|r|r|r|r|r|}
\hline & \multicolumn{1}{|c|}{ B } & \multicolumn{1}{c|}{ S.E. } & Wald & df & \multicolumn{1}{c|}{ Sig. } & \multicolumn{1}{c|}{ Exp(B) } \\
\hline Character & 11,187 & 5,691 & 3,864 & 1 & 0,049 & $72.205,616$ \\
Liquidity & 0,996 & 0,441 & 5,098 & 1 & 0,024 & 2,706 \\
Leverage & 1,148 & 0,605 & 3,602 & 1 & 0,058 & 3,152 \\
History & 0,843 & 0,389 & 4,704 & 1 & 0,030 & 2,324 \\
Constant & $-29,832$ & 11,800 & 6,392 & 1 & 0,011 & 0,000 \\
\hline
\end{tabular}

In Table 12, the standard error of coefficients of independent variables (SE), Wald statistics (Wald), significance levels (Sig) and Exp (B) statistics are given. In logistic regression, Wald statistic, which has a specific distribution known as chi-square, is a measure of the significance of $\beta$ (Cokluk, 2010:1388). The variables including Character, Liquidity and History is found to be significant at $95 \%$ confidence level. The Leverage variable is found to be insignificant at $5 \%$ significance level and is not included in the model. Eventually, the model is constructed as follows;

$$
\text { In }\left[\frac{P}{1-P}\right]=-29,832+11,187 \text { Character }+0,996 \text { Liquidity }+0,843 \text { History }
$$

According to the model, as all three risk factors increases, the likelihood of a bank's credit rationing increases. Especially, the Character risk factor has significant impact on credit rationing compared to the other two factors. 


\section{CONCLUSION}

In credit markets, asymmetric information problem causes two major problems that are adverse selection and moral hazard. From banking perspective, the problem of information asymmetry leads to increase in operating cost and decrease in productivity, and during the economic or financial crisis period, it causes the bankruptcy of banks. Banks that face the problem of asymmetric information use credit rationing mechanism to reduce the default risk of their non-performing loans. Credit rationing occurs when lenders either does not issue the loan or reduce the amount of loanable funds for the borrowers.

In this study, the factors that affect the credit rationing in commercial loan markets have been investigated by using quantitative and qualitative decision parameters for 77 firms that operate in manufacturing sector. Logistic regression and discriminant analysis were employed in order to estimate the credit rationing. When correlation coefficients between variables, tolerance and VIF scores are examined, it is found that multicollinearity problem does not exist between the variables. The Durbin- Watson test result $(D W=2.373$ ) indicates that there is no autocorrelation problem. The Omnibus test result supports the relationship between the dependent and independent variables.

In this study, we examined probability of credit rationing with 12 different factors and found that morality, liquidity and credit history play significant role in loan approval procedure, as well as in credit rationing. Based on the methods, logistic regression and disciriminant analysis, there is a positive relationship between credit rationing and character, liquidity and credit history. In particular, the character variable, which is used as a morality risk, is a very important factor for decision makers in banks. In addition, compared to logistic regression, discriminant analysis yields better results on credit rationing estimation. The study can further be developed by using large sample that represents the whole commercial lending process in Turkey along with multiple periods.

\section{REFERENCES}

- $\quad$ Akyol, M. (2010). Türkiye'de Bankacılık Sektöründe Asimetrik Bilgi Sorunu ve Kredi Tayınlaması Arasındaki Nedensellik iliş̧kisi. Yüksek Lisans Tezi, Adnan Menderes Üniversitesi Sosyal Bilimler Enstitüsü İktisat Anabilim Dalı, Aydın, ss.55-59.

- $\quad$ Albayrak, A. S., (2006).Uygulamalı Çok Değişkenli İstatistik Teknikleri, 1. Baskı, Asil Yayın Dağıtım Ltd. Şti, Ankara.

- $\quad$ Aras G. ve Müslümov, A. (2004). Kredi Piyasalarında Asimetrik Bilgi ve Bankacılık Sistemi Üzerindeki Etkileri, iktisat, Işletme -Finans Dergisi, 222, pp. 55-65.

- Atalan, B. (2005). KOBi'lerin Kredilendirilmesi, Active, Ocak-Şubat. 
- $\quad$ Atiyas, Z., Ersel, H. ve Öztürk, E. (1993). Türk Bankalarinda Müşteri Deseni Ve Kredi Tayinlamasi. Türkiye Cumhuriyet Merkez Bankasi Tartişma Tebliği, no 9301A.

- Ayça, T. (2010). Asimetrik Enformasyon Işığında Halka Arzların Uzun Dönemli Performanslarının Değerlendirilmesi. Ekonometri ve Istatistik Dergisi, Sayı:12, ss.102-121.

- Ayrıçay, Y. ve Kök, D. (2009). Kobilerin Finansmanında Kredi Kullanım Düzeyini Etkileyen Faktörler: Kahramanmaraş Örneği. Mustafa Kemal Üniversitesi Sosyal Bilimler Enstitüsü Dergisi, 6, 11, ss. 109-131.

- Bekmez, S. ve Çalış, F. (2011). Oyun Teorisi Çerçevesinde Türk Bankacılık Sistemi ve Asimetrik Bilgi Problemi. Süleyman Demirel Üniversitesi Iktisadi ve Idari Bilimler Fakültesi Dergisi, C.16, S.2, ss.79-96.

- $\quad$ Bhaird C. ve Lucey B. (2006). "Capital Structure and the Financing of SMEs: Empirical Evidencefrom an Irish Survey". Entrepreneurship: Occupational Choice andFinancing Conferance, 6-7 June, Copenhagen: Centre for Economic and BusinessResearch.

- $\quad$ Boot, A. W. A., ve Thakor, A. V. (1994). "Moral Hazard and Secured Lending inan Infinitely Repeated Credit Market Game". International Economic Review, 35, 899-920.

- Cengiz, V. (2010). Finansal Piyasalarda Bilgi Problemlerinin Çözümünde Bankaların Rolü, Bilgi Ekonomisi ve Yönetimi Dergisi, Cilt: V Sayı: I, ss. 151-162.

- Ceylan, S. ve Durkaya, M. (2010). Türkiye'de Kredi Kullanımı - Ekonomik Büyüme İlişkisi. Atatürk Üniversitesi Iktisadi ve Idari Bilimler Dergisi, Cilt: 24, Sayı: 2, ss. 2134.

- Çeviş, ì. (2005). Para krizlerine ampirik bir yaklaşım, Sermaye Piyasası Kurulu, 187.

- Çokluk, Ö. (2010). Kuram ve Uygulamada Eğitim Bilimleri / Educational Sciences: Theory \& Practice 10 (3) • Yaz / Summer $2010 \bullet 1357-1407$.

- Drakos, K ve Giannakopoulos, N.(2011). On The Determinants Of Credit Rationing: Firm-Level Evidence From Transition Countries. Journal of International Money and Finance,pp. 1773-1790. 
- $\quad$ Elhan, A.H. (1997), Lojistik Regresyon Analizinin İncelenmesi ve Tıpta Bir Uygulaması. (Biyoistatistik Yüksek Lisans Tezi) A.Ü.,4-29, ANKARA.

- $\quad$ Elsas, R. ve Krahnen, J.P. (1998). "Is Relationship Lending Special? Evidence from Credit-fila data in Germany". Journal of Banking and Finance, 22, 1283-1316.

- $\quad$ Er, S. (2011). Finansal Krizleri Önleme Araci Olarak Finansal Sektörün Regülasyonu, Mortgage Krizi Ve Türkiye, Maliye Dergisi, Sayı 160, ss. 307-327.

- Erdoğan, M. (2008). Bankacılık Sektöründe Asimetrik Bilgi: Sorunlar ve Çözüm Önerileri. Dumlupınar Üniversitesi Sosyal Bilimler Dergisi, Sayı 20.

- $\quad$ Erdoğan, S. Ve Beşballı, S.G. (2009). Türkiye'de Banka Kredileri Kanalının İşleyişi Üzerine Ampirik Bir Analiz, Doğuş Üniversitesi Dergisi, 11 (1), ss.28-41.

- $\quad$ Fidan, M.M. (2011). Kobi Kredi Piyasasında Asimetrik Bilgi Ve Ahlaki Tehlike: Laleli Örneği. Maliye Finans Yazıları, 25 Sayı: 90, ss. 41-57.

- $\quad$ Field, A. (2005). Discovering statistics using SPSS (2nd ed.). London: Sage.

- Girginer, N. (2013). Ticari Kredi Taleplerinin Değerlendirmesine Çok Kriterli Yaklaşım: Özel ve Devlet Bankası karşılaştırması.http://journal.mufad.org/attachments/article/300/12.pdf (29.01.2013).

- Guiso, L. (1998). High-tech firms and credit Rationing. Journal of Economic Behavior \& Organization, Vol. 35, pp. 39-59.

- Hodgman, D. (1960)."Credit Risk and Credit Rationing", Quarterly Journal of Economics, 74, pp. 258-278.

- İşcan, E. (2010). Iktisat Teorisinde Enformasyon Sorununa Yönelik Yaklaşımlar. Doktora Tezi, Çukurova Üniversitesi Sosyal Bilimler Enstitüsü İktisat Anabilim Dalı, Adana, ss. 59-64.

- Jaffee D. M. ve Russell T. (1976)."Imperfect Information Uncertainty and Credit Rationing", Quarterly Journal Economics, pp. 651-666.

- Kalaycı, Ş. (2008), SPSS Uygulamalı Çok Değişkenli İstatistik Teknikleri, Asil Yayın, Ankara. 
- $\quad$ Klapper, L.F., Sarria-Allende, V. ve Zaidi, R. (2006). “A Firm-Level Analysis of Small and Medium Size Enterprise Financing in Poland", World Bank Policy Research Working Paper, 3984.

- $\quad$ Kutlar, A. (2005) "Uygulamalı Ekonometri" 2. Baskı, Ankara, Nobel Yayın Dağıtım.

- $\quad$ Kutlar, A. Ve Sarıkaya, M. (2003). Asimetrik Enformasyon Ve Marjinal Maliyet Fiyatlama Modeli Çerçevesinde Türkiye'de Kredi Tayınlaması Ve Faiz Oranlarının Tahmini. C.Ü. Iktisadi ve Idari Bilimler Dergisi, Cilt 4, Sayı 1.

- Menard, S. (1995). Applied logistic regression analysis. Thousand Oaks, CA: Sage.

- $\quad$ Mijida, N. ve Bernasek, A. (2012). Gender and the credit rationing of small businesses. The Social Science Journal.

- Mishkin, F.S. (1998). International Capital Movements, Financial Volatility and Financial Instability. NBER Working Paper No.6390.

- $\quad$ Myers, R. (1990). Classical and modern regression with applications (2nd ed). Boston, MA: Duxbury.

- Özdamar, K. (2004). Paket Programlar İle İstatiksel Veri Analizi. Genişletilmiş 5.Baskı. Eskişehir, Kaan Kitabevi.

- Özgür, E. (2011). Türk Bankacılık Sektörünün Kredi Arzını Etkileyen Unsurlar: Türk Bankacılık Sektöründe "Kredi Çöküşü". Yüksek Lisans Tezi, Ankara Üniversitesi Sosyal Bilimler Enstitüsü İktisat Anabilim Dalı, Ankara, ss.42-44.

- $\quad$ Seyrek, I.H., ve Ata, H. A., (2010), "Veri Zarflama Analizi ve Veri Madenciliği ile Mevduat Bankalarında Etkinlik Ölçümü”, BDDK Bankalılık ve Finansal Piyasalar Dergisi, Cilt 4, Sayı:2, ss 67-84.

- Shahnaz, Farial, Decision Tree Based Algorithms, Michael W. Berry (Ed.), Lecture Notes in Data Mining, World Scientific Publisher, USA 2006.

- $\quad$ Stiglitz, J. E. ve Weiss A. (1981). "Credit Rationing in Markets with Imperfect Information", American Economic Review, 71, (3), ss.393-410.

- Tatlıdil, H. (1996). Uygulamalı çok değişkenli istatistiksel analiz. Ankara: Engin Yayınları. 
- Todman, J. Ve Dugard, P. (2007). Approaching multivariate analysis: An introduction for psychology. New York: Taylor \& Francis Group.

- Tükel, A. (2006). Asimetrik Enformasyon Işığında Kredi Tayınlaması ve Türkiye Uygulaması. Doktora Tezi, Maramara Üniversitesi Bankacılık ve Sigortacılık Enstitüsü Bankacılık Anabilim Dalı, İstanbul, ss.23-37.

- Vandel, K. (1984). Imperfect Information, Uncertainty and Credit Rationing: Comment and Extension, Quarterly Journel Of Economics, 79, ss. 847.

- Viner, J. (1937). Studies in the Theory of International Trade, Harper and Bross, New York.

- Williamson, S.D. (1987). Costly Monitoring,Loan Contracts and Equilibrium Credit Rationing. Quarterly Journel Of Economics, Vol.102, No.1, pp. 135-146.

- Yılmaz, A.B. (2003). Finansal Piyasalarda Asimetrik Bilgi ve Iktisadi Sonuçları.Yüksek Lisans Tezi, Akdeniz Üniversitesi Sosyal Bilimler Enstitüsü, Antalya,ss.33-47.

- Yiğitbaş, S.B.(2012). Bankaların Kredi Verme Davranışı Üzerine Asimetrik Bilginin Etkisi Ve Reel Sektör Yansıması (Türkiye Analizi 2002-2010), Türkiye Bankalar Birliği.34.Y.5327.288. 
APPENDIX 1: Dependent and Independent Variables

\begin{tabular}{|c|c|c|c|}
\hline Variables & Definition & Abbreviations & Codes / Value \\
\hline $\mathrm{Y}$ & Credit Rationing & Rationing & $1=$ Yes $\quad 0=$ No \\
\hline$x_{1}$ & Firm Size & Size & $\begin{array}{l}1=\text { Total Sales }>40.000 .000 \\
2=\text { Total Sales }<40.000 .000 \\
3=\text { Total Sales }<8.000 .000 \\
4=\text { Total Sales }<1.000 .000\end{array}$ \\
\hline$x_{2}$ & Firm Age and Ownership Structure & Age & $\begin{array}{l}1=\text { Risk Free } \\
2=\text { Low Risk } \\
3=\text { Risky } \\
4=\text { High Risk }\end{array}$ \\
\hline$x_{3}$ & Bank Relations & Relation & $\begin{array}{l}1=\text { Risk Free } \\
2=\text { Low Risk } \\
3=\text { Risky } \\
4=\text { High Risk }\end{array}$ \\
\hline $\mathrm{X}_{4}$ & Foreign Trade Status & Export & $\begin{array}{l}1=1=\text { Risk Free } \\
2=\text { Low Risk } \\
3=\text { Risky } \\
4=\text { High Risk }\end{array}$ \\
\hline$X_{5}$ & The Administrative Structure & Admin & $\begin{array}{l}1=\text { Risk Free } \\
2=\text { Low Risk } \\
3=\text { Risky } \\
4=\text { High Risk }\end{array}$ \\
\hline$x_{6}$ & Morality & Character & $\begin{array}{l}1=\text { Risk Free } \\
2=\text { Low Risk } \\
3=\text { Risky } \\
4=\text { High Risk }\end{array}$ \\
\hline$X_{7}(A)$ & Liquidity & Liquidity & $\begin{array}{l}1=\text { Risk Free } \\
2=\text { Low Risk } \\
3=\text { Risky } \\
4=\text { High Risk }\end{array}$ \\
\hline $\mathrm{X}_{7(\mathrm{~B})}$ & Asset Structure & Asset & $\begin{array}{l}1=\text { Risk Free } \\
2=\text { Low Risk } \\
3=\text { Risky } \\
4=\text { High Risk }\end{array}$ \\
\hline$X_{7(C)}$ & The Capital Structure and Leverage & Leverage & $\begin{array}{l}1=\text { Risk Free } \\
2=\text { Low Risk } \\
3=\text { Risky } \\
4=\text { High Risk }\end{array}$ \\
\hline$X_{7(D)}$ & Profitability, and Productivity & Profit & $\begin{array}{l}1=\text { Risk Free } \\
2=\text { Low Risk } \\
3=\text { Risky } \\
4=\text { High Risk }\end{array}$ \\
\hline$X_{7(E)}$ & The Performance Ratios & Performance & $\begin{array}{l}1=\text { Risk Free } \\
2=\text { Low Risk } \\
3=\text { Risky } \\
4=\text { High Risk }\end{array}$ \\
\hline$X_{8}$ & Credit History & History & $\begin{array}{l}1=\text { Risk Free } \\
2=\text { Low Risk } \\
3=\text { Risky } \\
4=\text { High Risk }\end{array}$ \\
\hline
\end{tabular}


APPENDIX 2: Correlation Coefficients between Variables

\begin{tabular}{|c|c|c|c|c|c|c|c|c|c|c|c|c|}
\hline & Size & Age & Relation & Export & Admin & Character & Liquidity & Asset & Leverage & Profit & Performance & History \\
\hline Size & 1,00 & & & & & & & & & & & \\
\hline Age & 0,26 & 1,00 & & & & & & & & & & \\
\hline Relation & 0,10 & 0,33 & 1,00 & & & & & & & & & \\
\hline Export & 0,33 & $-0,07$ & 0,01 & 1,00 & & & & & & & & \\
\hline Admin & 0,05 & 0,30 & 0,60 & 0,08 & 1,00 & & & & & & & \\
\hline Character & 0,20 & $-0,03$ & 0,17 & 0,02 & 0,19 & 1,00 & & & & & & \\
\hline Liquidity & 0,05 & 0,17 & 0,29 & 0,16 & 0,27 & 0,13 & 1,00 & & & & & \\
\hline Asset & 0,24 & 0,22 & 0,10 & 0,21 & 0,27 & $-0,11$ & 0,16 & 1,00 & & & & \\
\hline Leverage & 0,16 & 0,34 & 0,49 & $-0,09$ & 0,35 & 0,07 & 0,53 & 0,14 & 1,00 & & & \\
\hline Profit & 0,17 & 0,09 & 0,13 & 0,12 & $-0,04$ & 0,10 & 0,11 & 0,28 & 0,25 & 1,00 & & \\
\hline Performance & 0,03 & 0,02 & $-0,01$ & 0,09 & $-0,11$ & $-0,14$ & 0,23 & 0,06 & $-0,06$ & $-0,08$ & 1,00 & \\
\hline History & 0,13 & 0,20 & 0,33 & 0,01 & 0,20 & 0,05 & 0,11 & 0,02 & 0,07 & $-0,04$ & $-0,05$ & 1,00 \\
\hline
\end{tabular}

